\title{
Chemical composition of the essential oil and hexanic fraction of Lippia and Lantana species
}

\author{
Pâmela S. Silva, ${ }^{1}$ Lyderson F. Viccini, ${ }^{1}$ Junya L. Singulani, ${ }^{1}$ Ezequias Pessoa de Siqueira, ${ }^{2}$ \\ Carlos L. Zani, ${ }^{2}$ Tânia M. A. Alves ${ }^{*}, 2$
}

\author{
${ }^{1}$ Departamento de Biologia, Universidade Federal de Juiz de Fora, Campus Universitário, 36036-330 Juiz de \\ Fora-MG, Brazil, \\ ${ }^{2}$ Laboratório de Química de Produtos Naturais, Centro de Pesquisas René Rachou, Fiocruz, Av Augusto de Lima, \\ 1715, 30190-002 Belo Horizonte-MG, Brazil.
}

\begin{abstract}
RESUMO: "Composição química do óleo essencial e fração hexânica de espécies de Lippia e Lantana". Foi realizada a comparação entre dois métodos de extração dos compostos voláteis obtidos de seis espécies de Verbenaceae, coletadas na Serra do Cipó, Minas Gerais, Brasil. Os óleos essenciais e as frações hexanica obtidos das folhas de duas espécies de Lantana e quatro espécies de Lippia, coletadas em duas diferentes estações do ano, foram analisados por CG/EM. Grande número de constituintes foi identificado nas amostras oriundas dos dois métodos de extração e o componente majoritário para a maior parte das espécies foi o $\beta$-cariofileno, seguido pelo germacreno $\mathrm{D}$, biciclogermacreno e $\alpha$-pineno. Para os dois gêneros estudados, foram observadas pequenas diferenças na composição do óleo essencial e fração hexânica. Esses resultados sugerem que a análise da fração hexânica pode ser usada para identificar os componentes voláteis majoritários dessas espécies, além de ser uma técnica alternativa para a análise dos compostos voláteis presentes no óleo essencial, uma vez que ambos mostraram composição similar.
\end{abstract}

Unitermos: Lippia, Lantana, Verbenaceae, óleo essencial, fração hexânica, CG/EM.

\begin{abstract}
A comparison between two extraction approaches of volatiles compounds from six species of Verbenaceae collected at Serra do Cipó, Minas Gerais, Brazil was done. The essential oil and hexanic fraction of leaves from two Lantana and four Lippia species collected in two different seasons were analyzed by GC/MS. Among various identified compounds from both extraction methods the majority of species showed major amounts of $\beta$-caryophyllene followed by germacrene $D$, bicyclogermacrene and $\alpha$-pinene. Few differences were observed between the composition of essential oil and the hexanic fraction regarding the two studied genera. These results suggest that the analysis of hexanic fraction can be used, as an alternative way, to analyze the volatile compounds of the essential oil.
\end{abstract}

Keywords: Lippia, Lantana, Verbenaceae, essential oil, hexanic fraction, GC/MS.

\section{INTRODUCTION}

Lippia and Lantana (Verbenaceae) are two native genera from Central and South America and Tropical Africa (Mondenke, 1980) that possess many medicinal and economically important species.

Nearly 150 species can be found in the genus Lantana and some of them are popularly used to treatment of several diseases (Boily \& Van Puyvelde, 1986; Silva et al., 2005). Some of the pharmacological properties have been studied including bronchorelaxing (Achola \& Munenge, 1996), anti-inflammatory and antinociceptive (Silva et al., 2005), antimycobacterial (Jimenéz-Arellanes et al., 2007), antimicrobial and antimutagenic (Barre et al., 1997; Hernández et al., 2005) and inhibitors of human thrombin activities (O’Neill et al., 1998). Among the species of the genus, the essential oil of the Lantana camara L. is the most studied one (Saleh, 1974; Deena \& Thoppil, 2000; Misra \& Laatch, 2000; Abdel-Hady et al., 2005; Walden et al., 2009).

The genus Lippia comprises 250 species of herbs, shrubs and trees. Several species are used in folk medicine as an alternative to currently used drugs due to their known analgesic, anti-inflammatory, antipyretic, sedative, antifungal, antihypertensive, diuretic, larvicidal, antimicrobial, antiviral, molluscicidal, antimalarial, 
antispasmodic, anticonvulsant and stimulant activities (Valentin et al., 1995; Pascual et al., 2001; Abena et al., 1998; Monteiro et al., 2007). Concerning the chemical and pharmacological studies, Lippia alba (Mill.) N.E. Brown and Lippia sidoides Cham. are the most studied species. Recently, the composition of the essential oil from leaves and flowers of Lippia lacunosa Mart. and Shau. and Lippia rotundifolia Cham. were reported (Leitão et al., 2008).

Considering that the genera Lippia and Lananta possess many aromatic species, chemical studies of these genera reported mainly the composition of their essential oils. In addition, the volatile compounds can also be extracted using non-polar solvents, such as hexane (Simões \& Spitzer, 2007). These compounds constitutes important source of biological active molecules

The present study report and compare the chemical composition of the essential oil and the hexanic fraction of Lippia and Lantana species collected in two different seasons, accessed by gas chromatography-mass spectrometry (GC/MS) analysis.

\section{MATERIAL AND METHODS}

\section{Plant material}

Leaves of Lantana aff. fucata Lindl., Lantana fucata Lindl., Lippia aristata Shauer, Lippia aff. microphylla Cham., Lippia martiana Shau and Lippia salviifolia Cham. were collected at Serra do Cipó (794 m; 19²7'47's 4333'10'”W), Espinhaço Range, Minas Gerais State, Brazil, during the dry (August/2004 and September/2005) and rainy (March/2005 and February/2006) seasons. The specimens were identified by Dr. Fátima Regina Gonçalves Salimena (Department of Botany, UFJF) and the vouchers were deposited at the CESJ Herbarium of the Federal University of Juiz de Fora (Table 1).

\section{Essential oil extraction}

The essential oils (EO) extracted from fresh leaves collected during the dry and rainy seasons, were obtained by hydrodistillation using a Clevenger-type apparatus for $2 \mathrm{~h}$. The chemical compositions of the EO were analyzed by GCMS. The EO from Lantana aff. fucata was not analyzed due to the absent of sufficient amount of leaves found during the dry season collection.

\section{Hexanic fraction}

Fresh leaves (at about $3 \mathrm{~g}$ ) were collected during the dry and rainy seasons, transferred to Falcon ${ }^{\mathrm{TM}}$ $50 \mathrm{~mL}$ conical tube containing $30 \mathrm{~mL}$ of ethanol P.A. The tubes were kept for one week at room temperature. After filtration, an aliquot of $100 \mu \mathrm{L}$ of the extracts was taken, mixed with the same volume of MilliQ water and finally partitioned twice with $n$-hexane. The chemical composition of the n-hexane fractions (HF) were analyzed by GCMS.

\section{Gas chromatography-mass spectrometry analyses}

The analysis was performed on a Shimadzu gas chromatograph-mass spectrometer model QP5050A equipped with a FID detector and a DB-5 fused silica capillary column $(35 \mathrm{~m} \times 0.2 \mathrm{~mm}$, film thickness 0.10 $\mu \mathrm{m})$, using helium as a carrier gas $\left(1.0 \mathrm{mLmin}^{-1}\right)$. The injector temperature was $200{ }^{\circ} \mathrm{C}$ and the column oven program was $50{ }^{\circ} \mathrm{C}$ to $200{ }^{\circ} \mathrm{C}$ at $4{ }^{\circ} \mathrm{C} \mathrm{min}{ }^{-1}$. The mass spectra were obtained by electronic impact $70 \mathrm{eV}$ and the range from 50 to $500 \mathrm{~m} / z$ was scanned. Data acquisition and handling was done via CLASS 5000 Shimadzu software. Retention Index (RI) in the range of 900 to 3000 was generated from analysis of a standard mixture containing $\mathrm{C}_{9}$ to $\mathrm{C}_{30}$ hydrocarbons. The oil constituents were identified by comparison of their mass spectra with those in a Shimadzu spectral database and RI (Adams, 1995).

\section{RESULTS AND DISCUSSION}

The results of the essential oils and hexanic fractions quantifications from leaves of Lantana and Lippia species collected during the dry and rainy seasons can be seen in Table 1. The yield of the hexanic fraction

Table 1. Percentage yields of essential oil (EO) and hexanic fraction (HF) (w/w) of Lantana and Lippia species from dry and rainy seasons.

\begin{tabular}{lcccc}
\hline \multirow{2}{*}{ Species } & $\begin{array}{c}\text { Vouchers numbers } \\
(\text { CESJ) }\end{array}$ & Dry season & EO (\%) & HF $(\%)^{\mathrm{b}}$ \\
\cline { 3 - 4 } Lantana aff. fucata & 48.653 & $\mathrm{a}$ & 0.16 & 0.24 \\
Lantana fucata & 32.730 & 0.02 & 0.04 & 0.10 \\
Lippia aff microphylla & 47.445 & 0.01 & 0.13 & 0.39 \\
Lippia aristata & 48.652 & 0.01 & 0.02 & 0.45 \\
Lippia martiana & 47.477 & 0.02 & 0.16 & 0.22 \\
Lippia salviifolia & 47.444 & 0.20 & 0.28 & 0.20 \\
\hline
\end{tabular}

${ }^{\mathrm{a}}$ not analyzed; ${ }^{\mathrm{b}}$ average of dry and rainy seasons. 
(w/w) was the same in both seasons and the yield of the HF was about twice higher than yield of the essential oil of Lantana and Lippia species in the rainy period, except for Lippia salviifolia that yields the same amount with the two methods.

Major components identified in the essential oil and hexanic fraction from leaves of Lantana and Lippia species were qualitative and quantitatively analyzed by GC/MS. The list of compounds according to their retention times can be seen in Tables 2 and 3 .

The identified compounds are similar to those ones previously reported to other Lantana species (Muhayimana et al. 1998; Da Silva et al., 1999). The EO and HF of both Lantana species are mainly composed by $\beta$-cariophyllene and germacrene $\mathrm{D}$ (Table 2). The results obtained for Lantana fucata, compared with another sample collected at Northeast of Brazil, showed that the oil of this species is rich in sesquiterpenes, mainly $\beta$-cariophyllene. However, the bulnesol, the third most abundant compound reported by De Oliveira et al. (2008) were not detected in our analysis. Probably, the difference of their chemical composition can be a consequence of their geographical origin. The major compounds of HF from Lantana aff. fucata collected during dry and rainy seasons were $\beta$-cariophyllene, germacrene $\mathrm{D}$, and bicyclogermacrene while for $\mathrm{EO}$ these compounds were found as major ones only for plants collected during the rainy season. Similarly, the $\mathrm{HF}$ and $\mathrm{EO}$ of $L$. fucata collected in both seasons possess germacrene $\mathrm{D}$ and $\beta$-cariophyllene as major compounds (Table 2). Furthermore, HF and EO observed for plants collected during the dry season showed high content of bicyclogermacrene, while the HF observed from leaves collected in rainy season was composed by ß-elemene, $\alpha$-guaiene and $\delta$-guaiene too.

Considering the Verbenaceae family, the genus Lippia are in outstanding position due to the great production of volatile compounds. The chemical

Table 2. Chemical composition of the essential oil (EO) and hexanic fraction (HF) of Lantana aff. fucata and Lantana fucata collected in dry and rainy seasons (RI: retention index)

\begin{tabular}{|c|c|c|c|c|c|c|c|c|c|c|}
\hline & \multirow{3}{*}{ Compounds } & \multirow{3}{*}{ RI } & \multicolumn{3}{|c|}{ Lantana aff. fucata (\%) } & \multicolumn{4}{|c|}{ Lantana fucata $(\%)$} & \\
\hline & & & \multirow{2}{*}{$\begin{array}{l}\text { Dry } \\
\text { HF }\end{array}$} & \multicolumn{2}{|c|}{ Rainy } & \multicolumn{2}{|c|}{ Dry } & \multicolumn{2}{|c|}{ Rainy } & \\
\hline & & & & $\mathrm{EO}$ & $\mathrm{HF}$ & $\mathrm{EO}$ & $\mathrm{HF}$ & $\mathrm{EO}$ & $\mathrm{HF}$ & \\
\hline$\alpha$-pinene & & - & - & 0.68 & - & - & - & - & - & \\
\hline sabinene & & - & - & 7.41 & - & - & - & - & - & \\
\hline B-pinene & & - & - & - & - & - & - & - & 15.64 & \\
\hline limonene & & 1033 & 1.53 & 2.00 & 1.60 & - & - & - & - & \\
\hline ß-cis-ocimene & & 1042 & - & 0.62 & - & - & - & - & - & \\
\hline$\beta$-trans-ocimene & & 1052 & - & 0.75 & - & - & - & - & - & \\
\hline$\Gamma$-terpinene & & 1063 & - & 0.29 & - & - & - & - & - & \\
\hline 4-terpinol & & 1187 & - & 0.35 & - & - & - & - & - & \\
\hline$\alpha$-copaene & & 1385 & 2.50 & 1.07 & 1.89 & - & - & - & - & \\
\hline ß-bourbonene & & 1394 & - & 1.13 & 2.38 & 1.19 & - & 2.10 & - & \\
\hline ß-elemene & & 1401 & - & 0.99 & - & 2.06 & - & 0.84 & 15.14 & \\
\hline ß-cariophyllene & & 1430 & 23.88 & 18.82 & 19.71 & 11.92 & 26.13 & 32.41 & 12.03 & \\
\hline$\alpha$-humulene & & 1465 & 1.75 & 2.50 & 2.26 & 6.38 & 9.75 & 4.17 & - & \\
\hline aloaromadendrene & & 1473 & 2.50 & 1.58 & 2.09 & 1.06 & - & 1.25 & - & \\
\hline$\Gamma$-muurolene & & 1489 & - & 0.51 & - & - & - & - & - & \\
\hline germacrene D & & 1493 & 47.27 & 32.82 & 43.65 & 15.96 & 45.46 & 32.29 & 20.10 & \\
\hline$\alpha$-guaiene & & 1499 & - & 0.32 & - & - & - & - & 10.67 & \\
\hline bicyclogermacrene & & 1510 & 7.09 & 11.57 & 12.22 & 10.46 & 14.27 & 2.48 & - & \\
\hline germacrene A & & 1519 & - & 1.56 & 1.71 & - & - & - & - & \\
\hline$\Delta$-guaiene & & 1519 & - & - & - & 4.47 & - & 1.55 & 21.17 & \\
\hline$\Gamma$-cadinene & & 1529 & - & 0.48 & - & 3.99 & - & 0.27 & - & \\
\hline$\Delta$-cadinene & & 1536 & 1.84 & 1.27 & 1.61 & 2.08 & - & - & - & \\
\hline germacrene B & & 1573 & 5.33 & 3.09 & 4.27 & 5.62 & - & 9.62 & 5.21 & \\
\hline germacrene D-4-ol & & 1593 & - & - & - & - & - & 0.52 & - & \\
\hline spathulenol & & 1595 & - & 2.17 & - & 2.42 & - & - & - & \\
\hline cariophyllene oxide & & 1601 & - & 1.74 & - & 6.08 & - & 6.70 & - & \\
\hline viridiflorol & & 1605 & 1.53 & 2.91 & 2.16 & 3.06 & - & - & - & \\
\hline \multirow[t]{2}{*}{ Total identified } & & 95.22 & 96.63 & 95.55 & 76.75 & 95.61 & 94.20 & 99.96 & & \\
\hline & & & & & & & & \multicolumn{2}{|c|}{$\begin{array}{r}\text { Rev. Bras. Farmacogn. } \\
\text { Braz. J. Pharmacogn. } \\
\text { 20(6): Dez. } 2010\end{array}$} & 845 \\
\hline
\end{tabular}




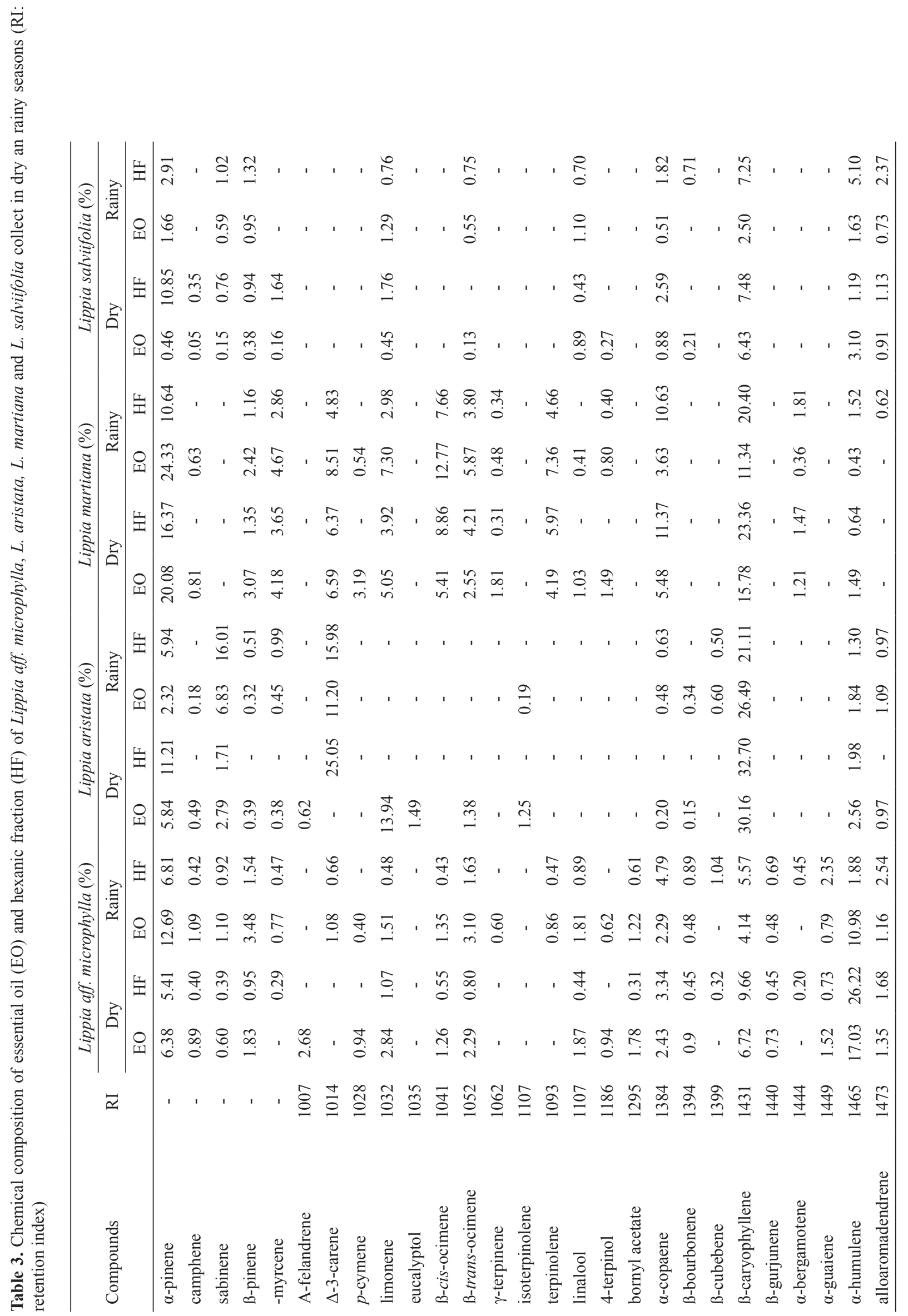




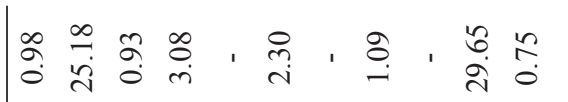

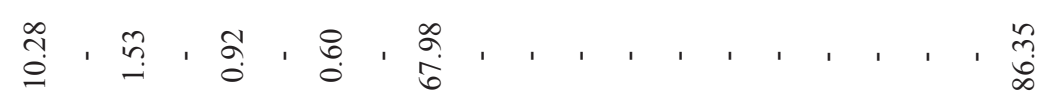

$$
\begin{aligned}
& \text { 苗 }
\end{aligned}
$$

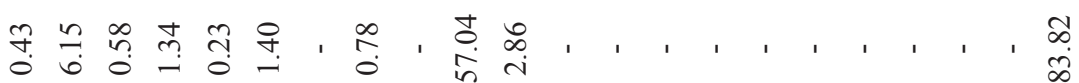

$$
\begin{aligned}
& \text { 市 } \begin{array}{l}
\infty \\
0 \\
0
\end{array} \\
& \text {, } 1,1, \frac{\infty}{0}, 1, \frac{n}{n}, 1 \frac{n}{0}, 1,1,1,1,1,1, \frac{\Omega}{\infty}
\end{aligned}
$$

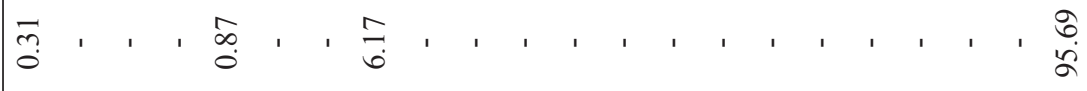

$$
\begin{aligned}
& \text { サ, , }
\end{aligned}
$$

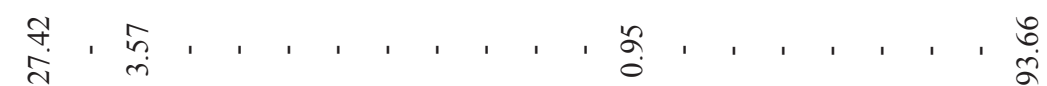

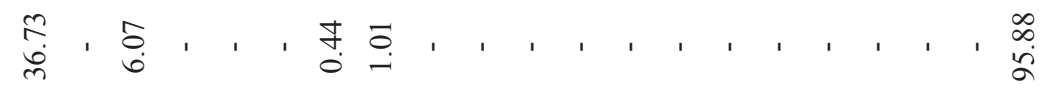

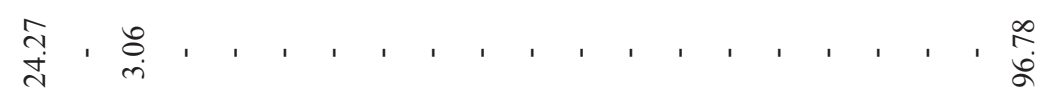

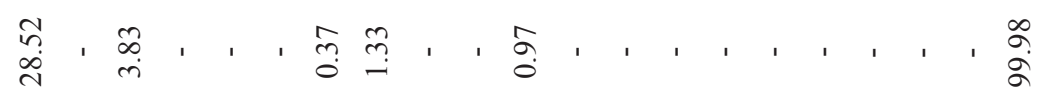

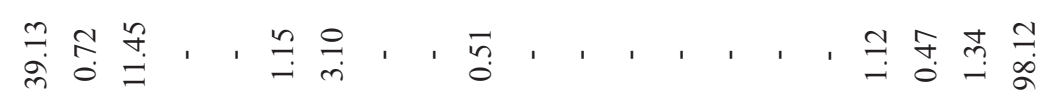

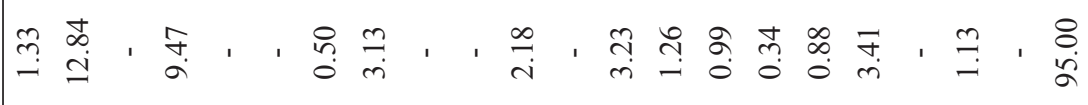

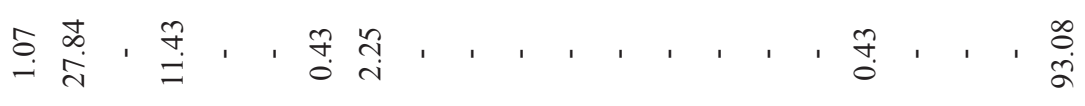

$$
\begin{aligned}
& \text { શ } \\
& \text { 交 守 }
\end{aligned}
$$

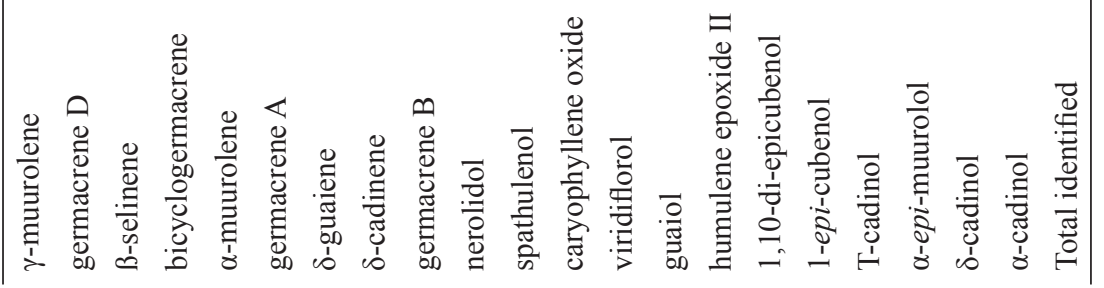


composition of the essential oils from many species has been investigated by gas chromatographic techniques. Limonene, $\beta$-caryophyllene, $p$-cymene, camphor, linalool, $\alpha$-pinene and thymol are the components which were found in the highest frequency (Pascual et al., 2001). The $\mathrm{OE}$ and HF of Lippia species investigated in the present study were mainly composed by sesquiterpenes (Table 3 ). Among them, for Lippia aff. microphylla collected in dry and rainy periods, bicyclogermacrene and germacrene D were the main compounds, while the major monoterpene was $\alpha$-pinene. Our data are in accordance with those previously reported to other Lippia species although thymol and 1,8-cineole were not identified by Costa et al. (2005) for Lippia microphylla. These differences may be explained by many factors such as soil, climatic conditions and also different genotypes (Baydar et al., 2004)

Lippia aristata, in all samples from dry and rainy seasons, showed high content of sesquiterpenes such as $\beta$-cariophyllene and germacrene D (Table 3). Among the monoterpenes, in all seasons, $\alpha$-pinene and sabinene were identified both in EO and HF. The $\delta-3-$ carene was identified in the $\mathrm{FH}$ of plants collected in dry season and in the EO and FH of leaves collected in rainy season, while the limonene was only identified in EO from individuals collected during dry season. Indeed, sabinene, limonene, $\delta$-3-carene, $\alpha$-pinene and $\beta$-cariophyllene were also previously identified as major compounds in the essential oil of the other Lippia species (Craveiro et al., 1981; Terblanché \& Kornelius, 1996).

The essential oil and HF from Lippia martiana collected in dry and rainy seasons showed higher level of the aromatic monoterpenes $\alpha$-pinene and $\delta$-3-carene (Table 3). The main sesquiterpene identified was $\beta$-cariophyllene.

The analysis of EO and HF from leaves Lippia salviifolia collected during dry and rainy seasons revealed that they are composed mainly by sesquiterpenes such as germacrene $\mathrm{D}$ and $\beta$-cariophyllene. Nerolidol was the major compound detected (Table 3 ). Antitrypanosomal, antifungal and antiulcer are some of the pharmacological activities already described for this oxygenated terpene (Hoet et al., 2006; Lee et al., 2007; Klopell et al., 2007).

\section{CONCLUSIONS}

For the first time, the chemical composition of the essential oil and the hexanic fraction were reported for two Lantana and four Lippia species collected at Serra do Cipó, Minas Gerais, Brazil. In general, it was possible to observe few differences between the composition of essential oil and the hexanic fraction for both genera. As the essential oil technique demands large quantities of plant material when compared to hexanic fraction, the present results offer an alternative approach to analyze the volatile compounds especially of plants that have a small amount of material.

\section{ACKNOWLEDGEMENTS}

The authors gratefully acknowledge FAPEMIG and $\mathrm{CNPq}$ (Brazilian agencies) and FIOCRUZ for financial support.

\section{REFERENCES}

Abdel-Hady NM, Abdei-Halim AS, Al-Ghadban AM 2005. Chemical composition and insecticidal activity of the volatile oils of leaves and flowers of Lantana camara L. cultivated in Egypt. J Egypt Soc Parasitol 35: 687-698.

Abena AA, Ngondzo-Kombeti GR, Bioka D 1998. Psychopharmacologic properties of Lippia multiflora. Encephale 24: 449-454.

Achola KJ, Munenge RW 1996. Pharmacological activities of Lantana trifolia on isolated guinea pig trachea and rat phrenic nerve diaphragm. Int J Pharmacogn 34: 273276.

Adams RP 1995. Identification of Essential Oil Components by Gas Chromatography/Mass Spectrometry. San Diego: Academic Press Inc.

Barre JT, Borden BF, Coll JC, De Jesus J, de La Fuente VE, Janairo GC, Ragasa CY 1997. A bioactive triterpene from Lantana camara. Phytochemistry 45: 321-324.

Baydar H, Sagdic O, Özkan G, Karadogan T 2004. Antibacterial activity and composition of essential oils from Origanun, Thymbra and Satureja species with commercial importance in Turkey. Food Control 15: 169-172.

Boily Y, Van Puyvelde L 1986. Screening of medicinal plants of Rwanda (Central Africa) for antimicrobial activity. $J$ Ethnopharmacol 16: 1-13

Costa SMO, Santos HS, Pessoa ODL, Lemos TLG 2005. Constituents of the essential oil of Lippia microphylla Cham. from Northeast Brazil. J Essent Oil Res 17: 378379.

Craveiro AA, Alencar JW, Matos FJA, Andrade CHS, Machado MIL1981. Essential oils from Brazilian Verbenaceae genus Lippia. J Nat Prod 44: 598-601.

Da Silva MHL, Andrade EHA, Zoghbi MGB, Luz AIR, Da Silva JD, Maia JGS 1999. The essential oils of Lantana camara L. occurring in north Brazil. Flavour Fragr $J$ 14: 208-210.

De Oliveira JCS, Neves IA, Da Camara CAG 2008. Oil composition of two Lantana species from mountain forests of Pernambuco (Northeast of Brazil). J Essent Oil Res 20: 530-532.

Deena MJ, Thoppil JE 2000. Antimicrobial activity of the essential oil of Lantana camara. Fitoterapia 71: 453455.

Hernández T, Canales M, Avila JG, García AM, Martínez A, Caballero J, De Vivar AR, Lira R 2005. Composition and antibacterial activity of essential oil of Lantana achyranthifolia Desf. (Verbenaceae). J Ethnopharmacol 96: 551-554.

Hoet S, Stévigny C, Hérent MF, Quetin-Leclercq J 2006. 
Antitrypanosomal compounds from the leaf essential oil of Strychnos spinosa. Planta Med 72: 480-482.

Jimenéz-Arellanes A, Meckes M, Torres J, Luna-Herrera J 2007. Antimycobacterial triterpenoids from Lantana hispida (Verbenaceae). J Ethnopharmacol 111: 202-205.

Klopell FC, Lemos M, Sousa JP, Comunello E, Maistro EL, Bastos JK, de Andrade SF 2007. Nerolidol, an antiulcer constituent from the essential oil of Baccharis dracunculifolia DC (Asteraceae). Z Naturforsch 62: 537-542.

Lee SJ, Han, JI, Lee, GS, Park, MJ, Choi, IG, Na KJ, Jeung EB 2007. Antifungal effect of eugenol and nerolidol against Microsporum gypseum in a guinea pig model. Biol Pharm Bull 30: 184-188.

Leitão SG, de Oliveira DR, Sülsen V, Martino V, Barbosa YG, Bizzo HR, Lopes D, Viccini LF, Salimena FRG, Peixoto PH P, Leitão GG 2008. Analysis of the chemical composition of the essential oils extracted from Lippia lacunosa Mart. \& Schauer and Lippia rotundifolia Cham. (Verbenaceae) by gas chromatography and gas chromatography-mass spectrometry. J Braz Chem Soc 19: 1388-1393.

Misra L, Laatsch H 2000. Triterpenoids, essential oil and photooxidative $28 \rightarrow 13$-lactonization of oleanolic acid from Lantana camara. Phytochemistry 54: 969-974.

Moldenke HN 1980. A sixth summary of the Verbenaceae, Avicenniaceae, Stilbaceae, Chloanthaceae, Symphoremaceae, Nyctanthaceae and Eriocaulaceae of the world as to valid taxa, geographic distribution and synonymy. Phytologia Mem 3:1-629.

Monteiro MVB, de Melo Leite AKR, Bertini LM, de Morais SM, Nunes-Pinheiro DCS 2007. Topical anti-inflammatory, gastroprotective and antioxidant effects of the essential oil of Lippia sidoides Cham. leaves. J Ethnopharmacol 111: 378-382.

Muhayimana A, Chalchat JC, Garry RP 1998. Chemical composition of essential oils of Lantana trifolia L. from Rwanda. J Essent Oil Res 10: 547-549.

O'Neill MJ, Lewis JA, Noble HM, Holland S, Mansat C, Farthing JE, Foster G; Noble D, Lane SJ, Sidebottom PJ, Lynn SM, Hayes MV, Dix CJ 1998. Isolation of translactone-containing triterpenes with thrombin inhibitory activities from the leaves of Lantana camara. J Nat Prod 61: 1328-1331.

Pascual ME, Slowing K, Carretero E, Sánchez Mata D, Villar A 2001. Lippia: traditional uses, chemistry and pharmacology: a review. J Ethnopharmacol 76: 201214.

Saleh M 1974. Gas chromatographic analysis of the essential oil of Lantana camara L. varieties. Planta Med 25: 373375.

Silva GN, Martins FR, Matheus ME, Leitão SG, Fernandes PD 2005. Investigation of anti-inflammatory and antinociceptive activities of Lantana trifolia. $J$ Ethnopharmacol 100: 254-259.

Simões, CMO, Spitzer V 2007. Óleos voláteis. In Simões CMO, Schenkel EP, Gosmann G, Mello JCP, Mentz
1A, Petrovick PR. Farmacognosia: da planta ao medicamento. $5^{\circ}$ ed. Porto Alegre: Editora UFRGS, p. 467-495.

Terblanché FC, Kornelius G 1996. Essential oil constituents of the genus Lippia (Verbenaceae )- A literature review. $J$ Essent Oil Res 8: 471-485.

Valentin A, Pélissier Y, Benoit F, Marion C, Kone D, Mallie M, Bastide JM, Bessieres JM 1995. Composition and antimalarial activity in vitro of volatile components of Lippia multiflora. Phytochemistry 40: 1439-1442.

Walden AB, Haber WA, Setzer WN 2009. Essential oil compositions of three Lantana species from Monteverde, Costa Rica. Nat Prod Commun 4:105-108. 